\title{
LOCAL GOVERNANCE, SOCIO-SPATIAL DEVELOPMENT AND SEGREGATION IN POST-TRANSITION HUNGARY
}

\section{A B S S T R A C}

The rescaling of the state and the general governance changes we have witnessed in Western Europe since the sixties occurred in Hungary in the last 25 years. In this paper I revisit the literature on phenomena relating changes in urban planning governance brought about by neoliberal regimes, and highlight parallel issues in the after-transition Hungarian context. Challenges of local governance are discussed, focussing on the mechanisms that have fuelled segregation in the Hungarian urban context. The paper concludes that glocalisation has been the main outcome of the decentralisation of public administration also in Hungary, whereas more recently rolling out of the state through its development policies financed mainly from EU funds has attempted to address urban inequalities and segregation. In part, however, some of the urban rehabilitation attempts are based on 'diseconomies of conflict', which means that results may become unsustainable in the future. 


\section{INTRODUCTION}

In his influential historical review The Cities of Tomorrow. An Intellectual History of Urban Planning and Design in the Twentieth Century, Peter Hall reviewed not only what (and who) has been the engine of urban planning, but he also reviewed the societal changes behind the variations and phases of urban planning across the world's large cities starting from the end of the $19^{\text {th }}$ century. ${ }^{1}$ In this paper, I focus on the more recent past and attempt to grasp how the governance changes fuelled by neoliberalism can be tracked at the level of challenges of urban planning relating segregation. My starting point is the rescaling of the state and the general governance changes we have witnessed in Western Europe since the sixties. Similar changes occurred in Hungary, unsurprisingly quite belated, though, in the last 25 years. After revisiting the literature on phenomena relating changes in urban planning governance brought about by neoliberal regimes, and highlighting parallel issues in the aftertransition Hungarian context, the challenges of local governance are discussed. Here I focus on some selected mechanisms that have fuelled segregation in the Hungarian urban context. The paper concludes that glocalisation has been the main outcome of the decentralisation of public administration also in Hungary, whereas more recently rolling out of the state through its development policies financed mainly from EU funds has attempted to address urban inequalities and segregation. In part, however, some of the urban rehabilitation attempts are based on 'diseconomies of conflict', which means that their results may become unsustainable in the future.

\section{RESCALING OF THE STATE AND}

\section{ADDRESSING SOCIAL CHALLENGES IN URBAN GOVERNANCE}

Western Europe has witnessed great dynamics in urban governance in the period after 1960. This dynamics is strongly connected with the states' changing roles and capacities. Neil Brenner summed up the phases of urban restructuring and state reorganisation as follows: Spatial Keynesianism (early 1960s-early 1970s); Fordism in Crisis (early 1970s-early 1980s); Glocalization Strategies, Round I (1980s); and Glocalization Strategies, Round II (1990s). ${ }^{2}$ The main distinction between the phases is based on how the state has changed the scale, goals and tools of its interventions, and to what extent its manifestation in space altered. Whereas in Europe, until the early seventies the state was oriented towards territorial equalisation as a national project, in the consecutive periods it has rather facilitated the formation of competition strategies of urban areas by devolving economic and other regulation to lower tiers and assisting the re-concentration of assets into powerful or growth areas. Regarding the strong state phase, Brenner claims that: 
"Spatial Keynesianism represents a state-led scale-making project in two senses. First, it entailed the establishment of a system of subnational institutions for the territorial regulation of urban development. Second, it entailed the embedding of major local and regional economies within a hierarchically structured, nationally focused political-economic geography. Throughout the postwar period, local governments were subsumed within nationalized institutional matrices characterized by centralized control over local social and economic policies, technocratic frameworks of metropolitan governance, extensive interregional resource transfers and redistributive forms of national spatial planning. Taken together, such policies and institutions attempted to secure a structured coherence for capitalist growth (a) by transforming cities and regions into the localized building blocks for national economic development and (b) by spreading urbanization as evenly as possible across the national territory". ${ }^{3}$

Under these conditions, local governments had a more dependent position. However, when the seventies proved ineffective in balancing territorial inequalities despite large-scale equalisation efforts within the state borders, and at the same time the European project began to crystallise, there was a shift in state regulatory arrangements. The new arrangement relied on identifying and boosting growth areas (urban areas and agglomerations) further to make them more competitive, and to address social challenges on this scale. At the same time, general changes in public financing occurred: national levels faced drawbacks and local levels were forced to rely more on own initiatives and developments, and hence they were put on own development trajectories. According to Brenner, the 1980s unfolded the retrenchment of the national welfare states further resulting in a changed local governance concept. ${ }^{4}$

This new version of "entrepreneurial form of urban governance" was the guiding principle when cities in the European area launched economic development and regeneration strategies to attract more investment, and hence further contributed to interlocality competition. The process was fuelled by further devolution of formerly state-run functions to local level like economic development, social services and spatial planning, too. This process has brought about great institutional changes, with many autonomous development institutions, which could be controlled by unaccountable political and economic elites who aimed to re-concentrate or enhance socioeconomic assets within cities, and shift the emphasis from local welfare delivery to promotion of local economic development. This process of "glocalisation" aimed at accumulation 
of capital "(a) by promoting a systematic reconcentration of industry and population within each national territory's most competitive locations, (b) by permitting and even encouraging divergent, place-specific forms of economic governance, welfare provision and territorial administration within different local and regional economies, and (c) by institutionalizing intensely competitive relations, whether for public subsidies or for private investments, among major subnational administrative units". ${ }^{5}$

The nineties, however, show that too much inequality halts growth: metropolization and regionalisation were sought to balance inequalities whilst supporting competitiveness at the same time. Peck and Tickell go further to claim that "by the 1990s it had become clear that recurrent failures of a quasisystemic nature in areas like transport, food systems, and pollution, and even in financial and labour markets, called for responses outside the narrow repertoire of deregulation and marketization". ${ }^{6}$ Thus, a "downscaled spatial Keynesianism" has been introduced, and equalisation efforts become strong again, though only regarding a very constrained spatial unit - the city, in a glocalising context. ${ }^{?}$

The city with social conflicts is necessarily challenged by the "new" role and the available tools. Hence, urban planning had to invent a different approach. Guiliani and Bianchi point out that "instead of capitalism as the structuring principle in the political and spatial organisation of the city ... satisfaction of social needs [become] ... the guiding principle for urban planning". ${ }^{8}$ Supported by the urban movements, a more just urban space is being strived for. Still, the (g)localisation processes' effects represent limitations and benefits at the same time. Decentralisation, the basis for localisation, was thought to embody a different form of government.

This governance model was expected to

"Steer rather than row; be concerned about results rather than inputs; be more preventative rather than curative; deploy more innovative mixes of competitive market and collaborative community problem-to-solve; and enable and empower rather than directly provide. ... Not only was old-style centralist, hierarchical, rigid bureaucracy no longer nimble enough to respond flexibly to a complex, rapidly changing world, but also an enterprising public sector could operate more effectively on tap rather than on top, availing of the dormant potential of overlooked social productivity in the public". ${ }^{9}$ 
Peck and Tickell point to the fact that the above dimensions are actually contextualised in the neoliberal discourse. ${ }^{10}$ Neoliberal regimes "punish" urban areas that fail to sufficiently address challenges that hinder growth and economic prosperity. Thus, unsurprisingly, localism turns out to be more problematic for urban areas where there is a culmination of social issues and the growth and competition potentials seem to be more limited. Especially, the combination of localism and contested space seems to be problematic, whilst offering some solutions in the conflict over space and resources.

It seems that it is not 'the public' but the 'publics' that are in rivalry and planning based on and with a 'community' in terms of a population bound to a select spatial unit can turn out to be a counterproductive approach. "A planning process that responds mainly to the preferences of such local segregated areas risk reinforcing the division and ghettoization". ${ }^{11}$ If we consider the community or neighbourhood level being the micro-level, the city the meso-level and the national level the macro-level, it becomes obvious that the lowest level is the one where the social issues culminate and conserves these areas to perpetuate further down according to their historical pathway, that is, disconnected from the dynamics of the urban area they are enclaved in.

Urban regeneration approaches that drastically address this disconnected nature of run-down neighbourhoods can often fall into the trap of the "diseconomies of conflict", ${ }^{12}$ which means that in order to better serve the residents of such communities, the local governments or service providers create parallel services to make sure the community gets access to quality services that address their particular needs locally. Equivalent services are created instead of granting access to mainstream services outside the neighbourhood or those run by other ethnicities or groups with which the long lasting conflict has been enduring.

To conclude, the recent years have shown that the rescaling of the state in space, that is, devolution of numerous tasks and redesign of redistribution systems to make cities more competitive, left many cities alone to address social challenges. In part, the states have 'rolled out' to address some of the challenges more efficiently at a meso-spatial level. At the same time this has led to a particular position of run-down neighbourhoods within the (g)localisation concept of the city:

"Yet while zones of deeply impacted poverty and social exclusion may have been no-go areas for neoliberals during the 1980s, in its rollout guise neoliberalism is increasingly penetrating these very places, animated by a set of concerns related to crime, worklessness, welfare dependency, and social breakdown". ${ }^{13}$ 
In the next two sections I intend to illustrate exactly this process in post-transition Hungary, based on a brief historical review of decentralisation and what challenges urban segregation has been causing and what sort of interventions have been created that are in part highly "diseconomic" in Gaffikin's terms and hence remain vulnerable to financial cuts and regulatory rigidity.

\section{A BRIEF HISTORY OF DECENTRALISATION AND RECENTRALISATION IN HUNGARY SINCE 1990}

The political and economic transition of Hungary started in 1990 and turned the Hungarian administrative system upside down. The so-long deconcentrated council system with a strong county level was replaced by a system based on over three-thousand local governments, all with equal self-governing rights and a long list of duties. The duties were to be performed from revenues which were in part allocated by the central budget, and to another part from local revenues which had to be raised to cover them. The state transferred the ownership of many assets to the municipal governments who could privatize or sell many real estates (except for roads, cemeteries and public parks for example) to get a working capital for running the services and plan for investments. ${ }^{14}$

Beyond uneven economic opportunities in the immediate after-transition years, social restructuring contributed to increasing territorial disparities, as more backward regions hit by the effects of the transition had necessarily less success in raising revenues (e.g. due to much lower personal income tax revenues as they had many unemployed residents), and running services and getting developments boosting their localities. A couple of years later, already by 1994, the local "freedom" (both financial and in defining local level services and developments) has been curtailed significantly to manage the inner and foreign debt of Hungary, and expenditure on social services and education was severely cut back. Szegváry emphasized that this change - that is underfinancing of local governments - gave the momentum for local governments to react to the cut-backs by developing revenue generation strategies, like imposing local business taxes and other fees, and to look for options to perform compulsory tasks at lower costs, for example by outsourcing activities to forprofit or non-profit organisations..$^{15}$ The capacity of the local leadership and staff seemed to be a determining factor of the performance of local governments: in order to improve local capacity, trainings were put in place to transfer necessary knowledge to the local administration for running the municipalities. As municipalities have both "local matters" and "affairs of authority" to complete, this was especially important. The tasks relating affairs of public administration 
were and are organised in a deconcentrated manner (such as issuing building permits or undertaking steps relating child well-being, which are prescribed by central regulations) as opposed to municipal authority issues (such as organizing local service delivery).

Already the mid-nineties witnessed a restructuring of the fragmented local governance system: as of 1994, statistical micro-regions were established and from 1996, municipalities of micro-regions could ally and establish common institutions and services, and most importantly, launch developments and investments to achieve a more synergetic effect. For example, schools, kindergartens, health and social services could be run in voluntary association so as to share the costs of operation. As of the Act of XXI from 1996, microregions were considered the lowest tier of spatial and regional planning, and as of 2004, all micro-regions of Hungary were obliged to establish regional planning associations. This was especially important as a share of European Funds was allocated through and for micro-regions.

The micro-regions and micro-regional level associations acted until 2013, when the coordinative tasks were transferred to the newly established districts which have quite similar spatial coverage but have been established as deconcentrated organs, and most of the voluntary micro-regional level service provisions such as health and primary education were centralised. ${ }^{16}$ Along with this change, which was effectively launched in 2011 by establishing so-called governmentauthorities that step-by-step took over decentralised tasks and acted as onestop shops, many until-then decentralised tasks were lifted from the single municipalities to the newly established district authorities. This process affected not only day-to-day management of authorization related tasks, but also affected social, health and education service delivery, and the funding and provision of various labour market services. The municipalities' resources via the redistribution system have been restructured considerably. ${ }^{17}$

Planning and design of local (spatial) development has remained the task of the local municipality, whereas service delivery which is crucial in terms of social inclusion has been transferred to the districts.

The above process is similar to what has been described as a process of rescaling of the state in space in the section above, as it demonstrates how decreasing and increasing of the presence of the state can occur at the same time. This is the context of the still ongoing reshaping of spatial inequalities in Hungary, which is the subject of the next section of the paper. 


\section{ISSUES OF SOCIO-SPATIAL DEVELOPMENT AND}

\section{URBAN SEGREGATION IN HUNGARY}

Already at the beginning of the nineties, local governments received the responsibility to provide for most of the public utility services, social services and basic health services at local level. They responded to this challenge with varying models, in terms of organizational structure and cooperation among settlements, and quality of provision. Insufficiency of central grants and the necessity to raise own resources or draw on loans were very common to cover the compulsory services and to complement them according to local needs. Thus, local governments and their service providing institutions have become genuinely uninterested in attracting or keeping population groups in their service areas that 'cost more', mostly population hit by poverty and exclusion.

In case there is a spatial concentration of socially vulnerable inhabitants, municipalities are even harder hit by service duties that demand additional funding. Evidence has shown that there are several responses to this increased needs: 1. do nothing and let the population live with low capacity services resulting in under-served areas and further downward perpetuation of the area due to under-investment into the services, 2 . increase service capacity and diversify it according to needs, 3. decrease public service delivery capacities further which would on the one hand result in an outflow of the inhabitants from the area, mostly followed by the inflow of even poorer residents as real estate prices may fall, and the creation of 'parallel' service delivery for example by charity organisations. ${ }^{18}$

Obviously, the availability and concentration of low cost housing, either in private ownership or as social housing are key elements of the decline of areas. In the Hungarian case, many times, such decline is also strongly connected with white flight. White flight has occurred as a reaction to the inflow of poor Roma families into declining neighbourhoods, many times fuelled by social housing allocation techniques, arrangements of housing privatisation and urban development policies of municipalities.

The history of the interplay of these three key elements (social housing allocation techniques, arrangements of housing privatisation and urban development policies of municipalities) goes back to as far as the before transition years, but often times also the urban development processes of the early twentieth century and after World War II years have defined the foundations of later development. The role of out-migration, downward housing mobility and local rehabilitation policies are factors that have contributed to spatial concentration of Roma. ${ }^{19}$ The processes in rural areas are even more rapid, and have started already back in the seventies. ${ }^{20}$ 
For example, extensive urbanisation in the beginning of the 1900s had been created by man-power that was also housed in the areas in low-comfort housing in selected transitory neighbourhoods, regularly in rented housing. ${ }^{21}$ These dwellings were nationalised after the World War by the beginning of the sixties and were operated as council housing with very low maintenance and investment levels until the transition. ${ }^{22}$ The next wave of urbanisation in the years of socialism went along with large scale (overwhelmingly prefab) housing construction. Whilst the first type of housing was often allocated to poorer families who could not afford investments or upgrade the homes and fell often in arrears with rent payments, the 'new' prefabs represented high quality housing with very good service delivery and often arranged in self-contained neighbourhoods, basically evoking the ideal of neighbourhoods that served as tied accommodation for professionals like miners or clerks around the turn of the $20^{\text {th }}$ century.

Around 1990, along with the general privatisation trends, a large share of the state owned housing stock was transferred to the municipalities (for the context, see above section), and housing privatisation in mass scale was launched. Out of the $199021 \%$ social housing stock, by the end of the nineties less than 5\% was in public hands. Only a very small stock was disclosed from selling, and it was rather the social conditions of the tenants that defined whether the housing could be purchased by the sitting tenants or not. ${ }^{23}$ The public stock got residualised: $44 \%$ of households where the head of a family was an unskilled worker lived in municipal rental, whereas this ratio was only $8.4 \%$ among the white-collar workers. ${ }^{24}$ Where social housing was concentrated, better-off families moved away, the rest being unable to privatise the homes due to low financial capacities or accumulated arrears. Municipalities tended to allocate housing in such areas rather to poorer families, which exacerbated the decline of such neighbourhoods. ${ }^{25}$ In other cases, if the location of the stock was strategically important because of the rent gap that could be endorsed in later years for example framed by urban rehabilitation projects, municipalities did not sell the homes to the sitting tenants and waited until time would come for launching the investments.

More recently, Hungary witnesses the repeated phenomenon of poverty suburbanisation which took first place in the early nineties when jobless households downgraded housing and moved to cheaper areas which at the same time meant less chance on the job market and lower service quality. This time, especially in areas with non-recovering post-transition economy and elsewhere also after the 2008 great financial crisis, outflow into neighbourhoods that serve and are classified as recreational areas with lack of even basic infrastructure supply, seem to attract the poorest of the poor, both from within and from outside the given town. ${ }^{26}$ In cases when it was the better-off who "occupied" such 
neighbourhoods, they could achieve the regularisation of the neighbourhoods by letting it reclassify as a residential area. However, in case these areas have become rather a pocket of poverty, municipalities tended to neglect the process and left these areas to be non-residential zones because this way they had no investment and service delivery obligation in the neighbourhood. ${ }^{27}$ This phenomenon is broadly similar to that in Serbia or elsewhere in the South East European countries.

\section{INCENTIVES FOR TACKLING SEGREGATION AND LOCAL PLANNING}

In Hungary, beyond exploring individual strategies and discrimination in general, special weight has to be given to local governments' interventions when we want to understand the mechanisms that foster segregation. Local governments are key players (even after the recentralisation trends of the past two years) because most of the service delivery and policies of spatial relevance for areas with high concentration of vulnerable groups are driven by them. Nevertheless, different authors may have different conclusions about exploring which element of the local governance system is the most powerful when it comes to fostering segregation. Whilst some deal with the constraints posed by the intergovernmental governance settings, ${ }^{28}$ others focus on how public players, including the (local) social sector, reproduces vulnerability because of its own institutional interests. ${ }^{29}$

With the EU accession, a new spatial dimension has been strengthened relating urban planning and development: to foster the competitiveness of the new member states, dedicated development funding has been steered to enhance the towns and cities, based on economic and social development. The EU-level action behind this process was the 2007 Leipzig Charta which described the main features of sustainable and inclusive urban development. Consequently, the Hungarian Government (the line Ministry responsible for urban development issues) changed the paradigm in urban development in Hungary, too, and beyond infrastructure and housing development it included a complexity of aspects in the planning process.

Thus, a supra-local "rule of the game" was imposed which at the same time contained a very a strong financial incentive for the local governments to think about addressing spatial challenges effectively. The social inclusion based development pillar was designed as a so-called social rehabilitation initiative in Hungary, with large-scale funding for investments in downward perpetuating and segregated neighbourhoods in towns, including the capital city of Budapest. With the support of the National Development Agency, any urban infrastructure 
related investment financed from EU funding was conditioned by the elaboration of a so-called integrated urban development plan, which had to take into account all spatial aspects of urban development, including focusing on the effects of urban processes on segregated urban neighbourhoods. In case there were segregated neighbourhoods in the cities, ${ }^{30}$ a special Desegregation (or Anti-segregation plan) had to be developed throughout a mentored process, supported by the Ministry for Social Affairs.

For example if there was a Roma neighbourhood in a town, the municipality had to work on a plan to make sure that the local processes and developments will be designed in the future in a way that the downward spiral of these neighbourhoods can be halted, and an action plan for this neighbourhood containing development or mainstream policy related measures (with a timeline and possible funding) had to be included in the Desegregation plan, too. The time scope of the plans was 2007/8-2013.

The social rehabilitation project plans included beyond infrastructure development social programs, such as education, health, community building, labour market interventions, etc. up to $5-15 \%$ of the project costs. The main innovation of the social urban rehabilitation projects is that they aim at handling both social exclusion of the residents and upgrading of the affected neighbourhoods. They do so by a profound needs assessment (framed by a strategic framework supported by a well elaborated methodology - the integrated urban development plans, the desegregation plans, and the detailed development plans for the action area), and a tailored composition of hard and soft development measures. There is a broad range of activities, depending on the selected projects. Mostly, the focus is on infrastructure development (roads, access to public utilities) and (social) housing refurbishment (regularly only from the outside), supported by some trainings and short-term employment programs. The most comprehensive program so far in Hungary has been running in Magdolna neighbourhood in Budapest District VIII, where the most important areas of intervention have been as follows: building of new and upgrading of old social housing, clearing tenancy rights, health programs, education programs, sports (new sports facilities), employment programs (mainly job search and trainings), anti-discrimination, community building (including establishing a new community centre), crime prevention (including CCTV), green area development/development of public space, transportation/ traffic development, intensive social work, including private homeowners into the housing actions, and last but not least road and pavement infrastructure development. As a result, Magdolna District has been 'put back' on the map of Budapest via the interventions, new private housing investments have launched and its status has improved - even if only slightly. 
To sum up, with the help of rescaling the responsibility of the state (by dedicating funding from the large EU budget), the local governments have been incentivised to address social exclusion within their administrative areas within a territorial approach whilst making use of all planning and design competencies they have, and relying on their service delivery capacities. Beyond more promising projects, some initiatives have demonstrated that in case service delivery is duplicated in the segregated neighbourhood, with the end of project financing the local government will face difficulties in maintaining the social inclusion and social work activities in the given neighbourhood, thus 'diseconomic' solutions may turn out to be problematic on the long run, and hence, the gap between the neighbourhood and the town will prevail.

\section{CONCLUSIONS}

In this paper, I summed up the governance changes that affected local urban agendas in the past decades. I showed some similarities between the posttransition Hungarian local governance system's challenges and those of WestEuropean glocalising cities. I argued that problematic spatial areas represent a special encounter: the decentralised governments are discouraged to deal with them, whereas, at the same time, they contest the development of the cities. Therefore, a re-rescaling of the state has been necessary to bring 'back' these areas' problems on the agenda. In Hungary this has happened with introducing a 'supra-national' rule of the game represented by EU funding and relating obligations. In part, however, some of the urban rehabilitation attempts are based on 'diseconomies of conflict', which means that their results may become unsustainable in the future.

NOTES

P. Hall, The Cities of Tomorrow. An Intellectual History of Urban Planning and Design in the Twentieth Century (Wiley/Blackwell: London, 2014).

Neil Brenner, "Urban governance and the production of new state spaces in western Europe, 1960-2000," Review of International Political Economy 11(3) (2004): 450.

Neil Brenner, "Urban governance and the production of new state spaces in western Europe, 1960-2000,", 462.

Neil Brenner, "Urban governance and the production of new state spaces in western Europe, 1960-2000,".

Ibid., 475 .

J. Peck, and A. Tickell, "Neoliberaliszing space.” Antipode (2004): 390.

Neil Brenner, "Urban governance and the production of new state spaces in western Europe, 1960-2000,", 478.

E. Gualini I. Bianchi, "Space, Politics and Conflicts," in Planning and Conflict. Critical Perspectives contentious urban development, edited by Enrico Gualini (New York: Routledge, 2015), 42. 
F. Gaffikin, "Paradoxes of local planning in contested societies," in Reconsidering Localism, edited by Simin Davoudi and Ali Madanipour, (London: Routledge, 2015), 34.

J. Peck, and A. Tickell, "Neoliberaliszing space,".

F. Gaffikin, "Paradoxes of local planning in contested societies,", 41.

Ibid., 44.

J. Peck, and A. Tickell, "Neoliberalising space,”, 395.

N. Teller, "Public Administration Reforms in Hungary," in Reforming Local Public

Administration: Efforts and Perspectives in South-East European Countries (Zagreb: Friedrich Ebert Stiftung, 2004), 58-67.

P. Szegváry, "Methods and Techniques of Managing Decentralization Reforms in Hungary," in Decentralization and Public Administration Reform. Mastering Decentralization and Public Administration Reforms in Central and Eastern Europe (Budapest: OSI/LGI, 2002), 137-162. Before the centralisation took place, all outstanding debts of the municipalities were covered by the state until the end of 2012. A large share of the debts was connected with operational loans, another one stemmed from loans to cover EU-funded investments' compulsory own resources. All 175 districts have towns as district centres. The remaining 153 towns are parts of the districts, irrespective of their size. Budapest, the capital city of 1.7 million inhabitants is divided into 23 districts. The total number of Hungarian municipalities is 3154. M. M. Urbánné, Nagyné, P.K. and Szabó, V., “A járási rendszer és az átalakított önkormányzati feladat ellátási struktúra kialakításának hatása a településekre," in Új hangsúlyok a területi fejlödésben. JATEPress, edited by Lukovics Miklós - Savanya Péter (Szeged, 2013), 261-279. http://www.eco.u-szeged.hu/ download.php?docID $=40056$

For cases see: N. Teller, "Vulnerable Groups and the Effects of Selected Local Government Service Delivery Policies in Three Hungarian Cities," in Who Decides? Development, Planning, Services, and Vulnerable Groups, edited by Pallai, K. (Budapest: OSI/LGI, 2009).

J. Hegedüs, "Lakásmobilitás a magyar lakásrendszerben," Statisztikai Szemle 79 (12) (2001): 934-955.

P. Beluszky and T. Síkos, Változó falvaink (Magyarország falutípusai az ezredfordulón) (Budapest: MTA TAKI, 2007); T. Virág, Kirekesztve. Falusi gettók az ország peremén (Budapest: Akadémiai Kiadó, 2010).

P. Germuska, "Ipari város, új város, szocialista város," Korall (11-12) 5 (2003): 239-259.

J. Hegedüs and I. Tosics, A lakásrendszer szociológiai és közgazdasági elemzése. Kandidátusi értekezés. 1993.

N. Teller, "Vulnerable Groups and the Effects of Selected Local Government Service Delivery Policies in Three Hungarian Cities," in Who Decides? Development, Planning, Services, and Vulnerable Groups, edited by Pallai, K. (Budapest: OSI/LGI, 2009).

G. Székely, “Az önkormányzati bérlakásszektor privatizációja,” Statisztikai Szemle (79)12 (2001): 955-969.

J. Hegedüs and N. Teller, „The privatisation of the housing stock in Eastern Europe: Hungary,” in The social limits to growth. Security and insecurity aspects of home ownership, edited by N. Horsewood and P. Neuteboom (Delft University Press, Volume 31 Housing and Urban Policy Studies, 2006.

No comprehensive research on this has been undertaken, but many cities report about this process. A press summary on this is available athttp://valasz.hu/reflektor/magyarorszag-gettoterkepe-57744 G. Csanádi, and A. Csizmady, "Szuburbanizáció és társadalom,” Tér és Társadalom 3 (2002): 27-57. J. Hegedüs, and N. Teller, Background study. Potential Demand for HLTAV Mortgages in Hungary, paper commissioned by GE Mortgage (manuscript), 2005.

J. Szalai, “A jóléti fogda.” I. Esély 6 (2004): 19-37.

The segregated neighbourhoods were defined as areas where more than $50 \%$ of the population had less than 8 finished years of education and were unemployed or inactive. These conditions can be easily met in neighbourhoods with an overrepresentation of Roma or retired persons (for example in older large scale housing estates). 
Beluszky, P. and Síkos T. Változó falvaink (Magyarország falutípusai az ezredfordulón). Budapest: MTA TAKI, 2007.

Brenner, Neil. "Urban governance and the production of new state spaces in western Europe, 1960-2000.” Review of International Political Economy 11(3) (2004): 447-488

Csanádi, G. and Csizmady, A. "Szuburbanizáció és társadalom.” Tér és Társadalom 3 (2002): $27-57$.

Gaffikin, F. "Paradoxes of local planning in contested societies." In Reconsidering Localism, edited by Simin Davoudi and Ali Madanipour, 30-53. London: Routledge, 2015.

Germuska, P. "Ipari város, új város, szocialista város.” Korall (11-12) 5 (2003): 239-259.

Gualini, E. and Bianchi, I. "Space, Politics and Conflicts." In Planning and Conflict. Critical Perspectives contentious urban development, edited by Enrico Gualini, 37-56. New York: Routledge, 2015.

Hall, P. The Cities of Tomorrow. An Intellectual History of Urban Planning and Design in the Twentieth Century. Wiley/Blackwell: London, 2014.

Hegedüs, J. “Lakásmobilitás a magyar lakásrendszerben.” Statisztikai Szemle 79 (12) (2001): 934-955.

Hegedüs, J. and Teller, N. Background study. Potential Demand for HLTAV Mortgages in Hungary, paper commissioned by GE Mortgage (manuscript), 2005.

Hegedüs, J. and Teller, N. "The privatisation of the housing stock in Eastern Europe: Hungary." In The social limits to growth. Security and insecurity aspects of home ownership, edited by N. Horsewood and P. Neuteboom, 137-160. Delft University Press, Volume 31 Housing and Urban Policy Studies, 2006.

Hegedüs, J. and Tosics, I. A lakásrendszer szociológiai és közgazdasági elemzése. Kandidátusi értekezés. 1993.

Peck, J. and Tickell, A. "Neoliberaliszing space.” Antipode (2004): 380-404.

Szalai, J. "A jóléti fogda.” I. Esély 6 (2004): 19-37.

Szegváry, P. "Methods and Techniques of Managing Decentralization Reforms in Hungary." In Decentralization and Public Administration Reform. Mastering Decentralization and Public Administration Reforms in Central and Eastern Europe, 137-162. Budapest: OSI/LGI, 2002.

Székely, G. “Az önkormányzati bérlakásszektor privatizációja.” Statisztikai Szemle (79)12 (2001): 955-969.

Teller, N. "Vulnerable Groups and the Effects of Selected Local Government Service Delivery Policies in Three Hungarian Cities." In Who Decides? Development, Planning, Services, and Vulnerable Groups, edited by Pallai, K. Budapest: OSI/LGI, 2009.

Teller, N. "Public Administration Reforms in Hungary." In Reforming Local Public Administration: Efforts and Perspectives in South-East European Countries, 58-67. Zagreb: Friedrich Ebert Stiftung, 2004.

Urbánné, M. M., Nagyné, P.K. and Szabó, V. “A járási rendszer és az átalakított önkormányzati feladat ellátási struktúra kialakításának hatása a településekre.” In Új hangsúlyok a területi fejlödésben. JATEPress, edited by Lukovics Miklós - Savanya Péter, 261-279. Szeged, 2013. http://www.eco.u-szeged.hu/download.php?docID $=40056$

Virág T. Kirekesztve. Falusi gettók az ország peremén. Budapest: Akadémiai Kiadó, 2010. 


\section{ULOGA LOKALNE UPRAVE U PROCESU REGENERACIJE BRAUNFILD LOKACIJA: EVROPSKA PLANERSKA PRAKSA \\ Ana Perić}

Pošto mnogobrojni učesnici sa različitim interesima u procesu braunfild regeneracije povećavaju složenost samog procesa, zanimljivo je posmatrati prirodu njihove saradnje. Fokus ovog rada je na ulozi lokalnih vlasti kao jednom od ključnih stejkholdera odgovornih za uspeh braunfild regeneracije. Položaj kao i instrumenti koje koristi lokalna uprava u datom procesu mogu se rasvetliti kroz posmatranje organizacije planskog procesa, pregovaračkih i procedura donošenja odluka, kao i načina rešavanja konflikata. Empirijski istraživački okvir ovog rada čine dve evropske studije slučaja braunfild regeneracije: nekadašnja fabrika kablova i žica u Beču i bivše romsko naselje u Budimpešti. Rad daje uvid u mogućnosti za redefinisanje planske kulture kroz inovativne i proaktivne planske pristupe braunfild regeneraciji.

KLJUČNE REČI: REGENERACIJA BRAUNFILDA, LOKALNA UPRAVA, KOLABORACIJA, BEČ, BUDIMPEŠTA

\section{LOKALNA UPRAVA, DRUŠTVENO-PROSTORNI RAZVOJ I SEGREGACIJA U POST-TRANZICIONOJ MAĐARSKOJ \\ Nora Teller}

Svedoci smo ponovnog skaliranja koncepta upravljanja u Zapadnoj Evropi poslednjih 25 godina. U ovom radu se daje pregled literature o pojavama koje se odnose na promene u upravljanju urbanim planiranjem izazvane uticajem neoliberalnog režima, i naglašavaju se paralelna pitanja u kontekstu post-tranzicione Mađarske. Izazovi lokalne samouprave su diskutovani kroz prizmu mehanizama koji su podstakli segregaciju u mađarskom urbanom kontekstu. U radu se zaključuje da je glokalizacija, podstaknuta nedavno razvijenim politikama rešavanja problema urbane nejednakosti i segregacije finansiranim iz fondova EU, glavni ishod decentralizacije javne uprave u Mađarskoj. Međutim, jednim delom neki od pokušaja urbane rehabilitacije su zasnovani na 'disekonomijama sukoba', što ukazuje da rezultati mogu postati neodrživi u budućnosti.

\section{KAPACITET “GLOKALNOG” UPRAVLJANJA: RUDARSKO NASLEĐE SARDINIJE}

\section{Nađa Beretić, Arnaldo Bibo Cecchini, Zoran Đukanović, Alessandro Plaisant}

Rad se bavi istraživanjem kapaciteta upravljanja rudnim industrijskim nasleđem Sardinije. Rudarska kultura Sardinije datira iz perioda od pre 8 hiljada godina, gde je oduvek predstavljala industrijski razvojni motor regiona, ugašena je '60-ih godina prošlog veka, a kasnije, 1997. godine, proglašena od strane UNESCO-a za nasleđe od izuzetnog značaja. Danas, ovi predeli se odlikuju izrazitom depopulacijom, i nedovoljnim kapacitetima upravljanja i rukovođenja; pejzaži izuzetne lepote imaju karakter osmišljenih, ali polu-doživljenih i pseudo-živih mesta. Istraživanje je pragmatične orijentacije, sa kvalititativnim karakterom; orijentisano da utvrdi šta i kako treba raditi u odnosu na željenu budućnost. Ono je multidisciplinarnog pristupa i uvek podrazumeva istraživanje u određenom društvenom, istorijskom, ekonomskom i političkom kontekstu.

Ispitivanje trendova i urbanih potencijala sardinijske teritorije rađeno je u komparaciji sa savremenom evropskom strategijom. Istraživanje govori o "zajedničkom kulturnom iskustvu" kao dugoročnoj komponenti održivosti, koja počiva, zasnovana je i pokreće se, na nivou lokalne zajednice.

Glavno pitanje rada razmatra "Glokalnu", lokalnu i globalnu, sposobnost upravljanja pomoću "ose partnerstva” (lokalni nivo - Parco Geominerario Storico e Ambientale - evropska i globalna mreža geoparkova - UNESKO), kao prve komponente kreativnog partnerstva, koja vodi ka integrisanju lokalne zajednice u participativni, kulturni, proces ponovnog razvoja, u kontekstu sardinijskog rudnog nasleđa kao održivog dizajna ovog sistema. 